\title{
HOW EVIDENTIAL IS THE EPISTEMIC CONDITIONAL?
}

\author{
AGNÈs CELLE \\ Université de Paris \\ agnes.celle@univ-paris-diderot.fr \\ ORCID: 0000-0002-7604-2659
}

\section{ABSTRACT $^{1}$}

This paper aims to reassess how - and if - the epistemic conditional in French relates to evidentiality, focusing on its use in reportative and non-reportative declarative sentences as well as in conjectural polar questions. It is proposed that the epistemic conditional developed from the modal hypothetical use, which accounts for its ability to establish an epistemic frame. The epistemic conditional is defined as a construction that conveys an assumption whatever the source of information. It is claimed that the epistemic conditional does not primarily encode information source. Although the epistemic nature of the epistemic conditional makes it prone to draw on reportative evidence, it is not primarily an evidential marker. Nonetheless, the epistemic conditional is claimed to have indirect evidential and mirative extensions. Rather than the type of information source, the conditional encodes the speaker's lack of control over information, which affects her level of commitment. Such an approach allows handling the different uses of the epistemic conditional in declarative sentences as well as in conjectural questions in a unified way.

KEYWORDS: conditional, epistemic modality, evidentiality, mirativity, assumption, conjectural, inferential, control.

\section{COM D’EVIDENCIAL ÉS EL CONDICIONAL EPISTÈMIC?}

\section{RESUM}

L'objectiu d'aquest article és reavaluar com es relaciona el condicional epistèmic amb l'evidencialitat - $\mathrm{i}$ si hi ha aquesta relació - posant el focus en l'ús del condicional en oracions declaratives reportatives i no-reportatives així com també en interrogatives totals de conjectura. S'hi proposa que el condicional epistèmic sorgeix de l'ús modal hipotètic, cosa que explica l'habilitat d'aquest mode per a establir un marc epistèmic. El condicional epistèmic es defineix com una construcció que expressa una assumpció, independentment de l'origen de la informació. S'afirma que el condicional epistèmic no codifica l'origen de la informació com a valor primari. Tot i que el caràcter epistèmic del condicional epistèmic el fa propens a basar-se en una informació reportada, no és un marcador evidencial en la seua funció primària. No obstant això, l'article defensa que el condicional epistèmic té extensions semàntiques evidencials i admiratives. El condicional codifica no tant el tipus d'origen de la informació sinó més aviat la manca de control sobre la informació del parlant, la qual afecta el seu nivell de compromís. Aquesta perspectiva permet unificar l'anàlisi dels diversos usos del condicional epistèmic tant en oracions declaratives com també en interrogatives conjecturals.

\footnotetext{
${ }^{1}$ I wish to express my thanks to the two anonymous reviewers for their valuable comments. Any errors are mine.
} 
MOTS CLAU: condicional, modalitat epistèmica, evidencialitat, admirativitat, assumpció, conjectura, inferència, control.

\section{INTRODUCTION}

This paper aims to determine how the epistemic conditional in French relates to evidentiality. The conditional is generally assumed to have three types of uses - a temporal one, a modal one typically found in the apodosis of conditional clauses and an epistemic one, also called "journalistic conditional". This paper focuses on the latter use and proposes that it developed from the modal one. It is claimed that the epistemic conditional became a construction. Although the epistemic conditional is typically found in reportative contexts, it is argued that secondhand information is not a part of its semantics. This is shown through applying diagnostics that are generally used to determine the semantic properties of reportative evidential markers across languages.

Epistemic uses that are unrelated to secondhand information are examined in declarative and interrogative contexts. The epistemic conditional is claimed to be able to draw inferences, which makes it difficult to distinguish between a purely reportative function and an inferential one. Crucially, the epistemic conditional does not encode information source and therefore cannot be deemed an evidential marker in the strict sense. As a primary exponent of a tense-modal system, it has indirect evidential and mirative extensions. Typically, these extensions arise when information is incomplete, uncertain or surprising. This paper proposes that evidential extensions should be recast in terms of epistemic control. In the first section of this paper, the state of the art of the threefold meaning of the conditional is presented. In the second section, epistemic distancing is defined in connection with the speaker's lack of control. The epistemic conditional is then examined in declarative sentences, both in nonreportative and reportative contexts. Drawing on the inferential dimension of the epistemic conditional, section 6 accounts for its use in conjectural polar questions.

\section{THE CONDITIONAL IN FRENCH: ULTERIORITY, MODAL HYPOTHETICAL MEANING, AND WHAT ELSE?}

The conditional conveys displacement, which can be manifested in different ways. It is generally assumed to express three types of displacement: ${ }^{2}$

- Temporal displacement, i.e. ulteriority

\footnotetext{
${ }^{2}$ Translations are mine unless otherwise specified. As the epistemic conditional is generally not translated into English, I have added the abbreviation COND as a subscript to the translation of the form that is inflected by the conditional in French.
} 
(1) En mars 2000, l'ONG a annoncé qu'une carte des cibles touchées par l'uranium appauvri au Kosovo serait remise au PNUE le mois suivant.

'In March 2000, the NGO announced that a map of targets affected by depleted uranium in Kosovo wouldcond be sent to UNEP the next month.'

- Modal displacement, i.e. hypothetical modality

(2) Si l'OTAN avait tenu ses promesses, une carte des cibles touchées par l'uranium appauvri aurait été remise au PNUE.

'If NATO had kept its promises, a map of targets affected by depleted uranium in Kosovo wouldcond have been sent to UNEP.'

- Epistemic distancing

(3) En mars 2000, le Military Toxics Project, ONG antinucléaire américaine, annonce qu'une carte des cibles touchées par l'uranium appauvri au Kosovo aurait été remise par l'OTAN au PNUE en janvier, information confirmée par une source du ministère des affaires étrangères des Pays-Bas. (Le Monde Diplomatique, February 2001)

'Last March the Military Toxics Project, an American anti-nuclear NGO, announced that Nato hadCond, that January, sent the UNEP a map of targets affected by depleted uranium in Kosovo; and this was confirmed by a source at the Netherlands foreign ministry.' (English Edition)

The conditional marks that the speaker disclaims responsibility for the proposition as it is based on information that was still unconfirmed - and therefore uncontrollable - when the announcement was made. There is no consensus on how to label the third meaning, which is variously called journalistic (Gosselin 2001), evidential (Dendale 1993), anaphoric (Azzopardi and Bres 2014), epistemic (Dendale 2018), or uncertainty conditional (Moeschler \& Reboul 2001). The secondhand information meaning is reported to be a consequence of the non-commitment meaning by Abouda (2001) while Haillet (2001) highlights the expression of enunciative otherness as a distinctive feature of the epistemic meaning. How to account for this meaning has been much debated. Three types of position are upheld:

i) the epistemic meaning is derived from the temporal meaning (Gosselin 2001). The -RAIS morpheme, a combination of the imparfait morpheme (-AIS) and the future morpheme (-R), accounts for the twofold temporal relationship denoted by the conditional: the source situation (i.e. the announcement made in March 2000 in example 3) is anterior to the speaker's here-and-now while the past event expressed by the passive past conditional (i.e. the map having been sent in January) is first considered possible at a posterior time that coincides with the time of utterance, until it is further confirmed;

ii) the epistemic meaning is derived from the modal meaning (Korzen \& Nolke 2001; Rossari 2009, 2018). Under this view, the conditional is taken to underlie a protasis-apodosis structure (Moeschler \& Reboul 
2001: 161), (Rossari 2018: 233, 236), such as "if the Military Toxics Project is correct" in (3);

iii) the second-hand information meaning is not derived from the temporal or the modal meaning. It is claimed to be a primary meaning of the conditional. More precisely, the conditional is claimed to be evidential (Dendale 1993, Kronning 2012).

Although our approach is not diachronic, it may be useful to build on the results of previous diachronic accounts, as they can bring valuable insight to the epistemic meaning of the conditional in present-day French. Diachronic studies have shown that the third meaning is historically more recent (Bourova \& Dendale 2013, Patard 2017). Based on diachronic evolution, Patard (2017) distinguishes between three different constructions of the same grammatical form, in the sense of construction grammar. The merit of this analysis is that it argues for a distinct epistemic construction, which, given its fairly recent development, cannot be considered to be a primary component of the conditional. ${ }^{3}$

In addition, Patard (2017) demonstrates that the Latin etymon had two distinct meanings. The conditional derives from the Latin periphrasis Infinitive + habere (have) in the imperfect tense. In Latin, the Infinitive + habebat structure breaks down into two distinct meanings - a predestination meaning stressing alethic necessity and a modal meaning in hypothetical si-sentences expressing the link between a condition and its necessary consequence (Patard 2017: 114). According to Patard (2017), there is reason to believe that the ulteriority conditional originates from the predestination meaning of the Latin periphrasis, ${ }^{4}$ whereas the hypothetical conditional derives from the modal meaning of the Latin periphrasis. In other words, two distinct meaning units grammaticalized into two distinct conditional constructions in French, one expressing ulteriority, and the other one hypothetical meaning, while the third construction, i.e. the epistemic construction supposedly dedicated to secondhand information meaning, appeared later. Following the hypothesis put forward by Bres, Azzopardi and Sarrazin (2012), Patard (2017: 121) argues that the secondhand information meaning is to be taken as a construction that developed from the temporal conditional construction expressing ulteriority. Example (4) is viewed as abstracting away from (5):

(4) Selon Sophie, Pierre participerait à la commémoration. (Patard 2017: 111)

\footnotetext{
${ }^{3}$ Similar claims have been made about evidential forms that derived from modal forms in other languages. For instance, within the speech act theory, Faller (2007: 5) distinguishes between two meanings of the modal verb sollen in German: "Thus, the case can be made that, synchronically, there are two modals sollen, a deontic and a reportative one."

${ }^{4}$ Bourova and Tasmowski (2007) similarly argue that the predestination meaning of the Latin periphrasis gave rise to the futurity meaning, which accords with the evolutionary path suggested by Bybee, Perkins, and Pagliuca (1994).
} 
'According to Sophie, Pierre iscond attending the commemoration ceremony.'

(5) Sophie dit que Pierre participerait à la commémoration. (Patard 2017: 111)

'Sophie said that Pierre wouldcond attend the commemoration ceremony.'

Under this view, the conditional in (4) refers to a previous report that is left implicit. The problem with this hypothesis is that an original reporting event is assumed. I argue below that such a conception cannot account for a variety of uses that are unrelated to a previous report.

The predestination meaning may well have given rise to the ulteriority meaning (5). However, the epistemic meaning illustrated in (4) does not convey necessity. The modalised proposition in (4) is presented as possible. Following Rossari (2009), it may be argued that the epistemic construction developed from the hypothetical use. Based on diachronic data, Rossari (2009: 86-88) shows that in the earliest occurrences of the epistemic use, the function of selon + NP in conditional sentences is to identify a point of view in a hypothetical frame. In the case of reportative prepositional phrases (selon les dires de / according to the statements of), it is the speaker's "extrapolation", i.e. her inferential reasoning, that is put in the foreground, based on reports that provide a hypothetical frame, while the report proper is in the background:

(6) Selon ton dire, il y en auroit un bien grand nombre de damnez et maudits de Dieu. (Palissy, 1563, cited by Rossari 2009: 88)

'According to your statement, there arecond quite a lot of damned villains cursed by God.'

Rossari (2009) suggests two different types of paraphrase: “Si l'on suivait ton dire" (if one followed your statement) to gloss the speaker's "extrapolation", and "si tu dis juste" (if you are right) to gloss the reportative meaning. Under this analysis, an underlying protasis provides a frame that accounts for the epistemic meaning of the conditional. The epistemic use is thus claimed to be a subcategory of the hypothetical use and not to denote secondhand information (Rossari 2009: $84-85,90,93)$.

The position argued for in the present paper is very close to Rossari's. It differs from the one frequently advocated in many recent accounts of the epistemic conditional, notably Dendale $(1993,2018)$ and Kronning (2012), who claim that the epistemic conditional is an evidential and that secondhand information is part of its semantics. This raises problems that are dealt with below.

Recent years have witnessed increased interest in evidentiality among linguists, sparked by the study of languages that encode information source either in their morpho-syntax (Aikhenvald 2004, Murray 2017) or with fully grammaticalised markers (Aksu-Koç \& Slobin 1986). How evidentiality is realised in languages that do not encode information source morphosyntactically, like French, remains a matter for debate. In French, tense is 
an obligatory category. Information source, however, need not be marked. In the following examples, it is not possible to determine whether the information conveyed by the speaker is based on first- or secondhand information:

(7) Des gilets jaunes ont saccagé l'avenue Kléber.

'Yellow vest protesters have ransacked Avenue Kléber.'

(8) Des gilets jaunes manifestent sur les Champs Elysées.

'Yellow vest protesters are demonstrating on Champs Elysées.'

(9) La Turquie n'arrêtera pas son offensive en Syrie.

'Turkey will not stop its offensive in Syria.'

In (7) and (8), the speaker may have direct knowledge of the events. In (9), the speaker may be expressing her own prediction. However, (7), (8) and (9) are equally compatible with secondhand information. In that case, the tense-aspect markers only indicate how these events are temporally located. They do not encode secondhand information. Crucially, reference to a potential original assertive source is lost (Grunig 1993) as the speaker does not have to specify what kind of evidence s/he has for making these claims. As a result, (7), (8) and (9) simply indicate that the speaker is committed to the truth of these propositions, regardless of what kind evidence s/he has for those claims.

Bearing this in mind, we can now return to the epistemic conditional. The epistemic conditional is highly frequent in reportative contexts such as journalistic discourse. However, as pointed out by Aikhenvald it does not follow that the conditional is an evidential, i.e. a marker of secondhand information: ${ }^{5}$

The conditional in French can be used for information obtained from a questionable secondhand source for whose veracity the speaker refuses to take responsibility. This does not mean that this conditional has 'become' an evidential. Rather, it has acquired a semantic extension to do with evaluating an information source. Categories and forms which acquire secondary meanings somehow related with information source are called evidential strategies. They are distinct from evidentials proper, whose primary - and not infrequently exclusive - meaning is information source. (Aikhenvald 2004: 105)

As stressed by Aikhenvald, the epistemic conditional may be used to evaluate an information source by signaling that the speaker disclaims responsibility for the proposition content. ${ }^{6} \mathrm{I}$ further argue that secondhand information is not a necessary component of the epistemic conditional.

${ }^{5}$ A similar view is defended in Cruschina and Remberger (2008: 98). Guentchéva (1994) also argues that French lacks an evidential system. Evidential meanings, however, may be expressed by the conditional, the passé composé, the present and the passive.

${ }^{6}$ De Haan (2012: 1034) expresses a similar caveat concerning inferential must in English. He points out that must is used to evaluate evidence, not to mark the source of evidence: "Evaluation of evidence is not necessarily the same as marking the source of the evidence, which is a simple assertion. We can of course broaden the definition of evidentiality to include evaluation but that would defeat the purpose of having a clear definition of evidentiality and we are running the risk 


\section{EPISTEMIC FRAME AND CONTROL}

As noted by several authors (Gosselin 2001: 61; among others), the epistemic construal is triggered by the lack of a past temporal point of reference. Without a past temporal point, the ulterior meaning is blocked, which leaves two options available. Either a protasis sets up a hypothetical condition (10a), or an epistemic interpretation is triggered by default (10b).

(10) (a) L'incendie se serait déclaré aux alentours de 18 heures si les pompiers n'avaient pas été appelés à 17 heures.

'The fire would have broken out around $6 \mathrm{pm}$ if the firefighters had not been called at 5 pm.'

(b) L'incendie se serait déclaré aux alentours de 18 heures [si l'on en croit les premiers éléments de l'enquête].

'The fire apparently brokecond out around $6 \mathrm{pm}$ [if the first results of the investigation are anything to go by].'

In the latter case $(10 \mathrm{~b})$, it is the time of speaking that serves as a reference point. Rossari (2009: 83) argues that the frame the epistemic conditional is anchored to is self-referential. The paraphrases she suggests to capture its meaning are all in the present tense, which shows the deictic anchoring of the epistemic conditional. The epistemic frame can be formulated in loose terms (if the first results of the investigation are anything to go by, if I understand correctly, to judge by appearances, if I am not mistaken, etc.). ${ }^{7}$ Whatever the formulation, the underlying protasis amounts to specifying the conditions under which the claim made is true. The epistemic frame functions as a restrictor with respect to the reliability of incomplete, uncertain or unexpected information available to the speaker at the time of speaking. The possibility of a proposition is asserted within an epistemic frame that need not be made explicit. As noted in all diachronic accounts, this meaning is fairly recent. The view upheld in this paper is that it developed from the hypothetical use. Now the question arises whether the modal conditional (10a) and the epistemic conditional (10b) should be deemed equivalent. ${ }^{8}$ Although both are related to some antecedent, the ability of the epistemic conditional to be construed epistemically without an explicit frame further suggests that it has become an epistemic construction.

that we end up with a definition that is not applicable crosslinguistically. There are clear differences between the evaluative use of must and for instance the Tuyuca Inferential."

7 The epistemic frame is dubbed "passe-partout» (one-size-fits-all) by Rossari (2009: 83).

${ }^{8}$ It should be stressed that the conditional cannot be embedded in the antecedent of a conditional. However, the epistemic conditional can provide an epistemic frame if it stands alone -i.e. if it is not embedded under silif: "Mais on voudrait chasser les paysans de la région qu'on ne s'y prendrait pas autrement" ['If the intention was to hound the peasants from the regions, you would not go about it any differently']. (Le Monde, cited in Celle 2007: 57). This use is beyond the scope of this paper. See Caudal (2018). 
The aim of this paper is to show that in French, a language that has a tensemodal system, this epistemic construction encodes the non-factual status of an utterance. If the information available to the speaker is unreliable or unexpected, the speaker may want to mark her lack of epistemic control ${ }^{9}$ (Langacker 2017) by resorting to epistemic distancing, though she does not have to do so. The choice of this strategy is speaker-oriented and has consequences on the speaker's level of commitment to the proposition.

The epistemic conditional is shown not to encode information source. Given that French has a tense-modal system, this comes as no surprise. As stated by Langacker (2017: 21), “a tense-modal system emphasizes time and reality, whereas an evidential system highlights the source and reliability of information". The epistemic conditional being part of a tense-modal system, it is not primarily related to information source. The tentative use of the conditional, for instance, as in je dirais (if I may say so), introduces an epistemic frame to mitigate an assertion (Abouda 2001: 286-93). This use of the conditional as a speech act specifier is epistemic but unrelated to evidentiality. Nonetheless, when evidential extensions arise, it is striking that they are all organised around report, inference and surprise. As different as they may seem, these meanings are known to pertain to the category of evidentiality (Guentchéva 1996, 1994). It seems, then, that within an epistemic frame, typical evidential extensions can arise. What motivates these evidential strategies is not the need to encode information source, but rather the attempt to achieve epistemic control. This conception of evidentiality is inspired from Langacker:

I view evidentiality as one dimension of epistemic assessment, which is best treated in a unified account of embodied experience and the striving for epistemic control. (Langacker 2017: 19)

\section{THE EPISTEMIC CONDITIONAL IN DECLARATIVE SENTENCES}

According to Dendale (1993, 2018), the epistemic conditional is characterised by three semantic components: ${ }^{10}$ i) it expresses uncertain information, hence its modal meaning; ii) it expresses secondhand information, which accounts for its evidential meaning; iii) it expresses the speaker's non-commitment, hence its alethic meaning. However, Dendale maintains that only secondhand information is a distinguishing feature, the first and the third components being subject to contextual variation. Dendale thus regards the evidential meaning of the

\footnotetext{
${ }^{9}$ Building on Langacker $(2017: 15,20)$, we regard epistemic control as knowledge of the world, "both real and mentally constructed": "At the mental level, we strive for epistemic control by building up a conception of reality, constantly augmented and adjusted on the basis of new experience."

10 To be more precise, Dendale (2018) includes a fourth component, borrowed from Gosselin (2001), namely posterior confirmation.
} 
epistemic conditional as its primary meaning and equates it with secondhand information. Under this view, the conditional is taken to be a grammatical marker of evidentiality in French.

Including respectively tentative uses and counterexpectational uses of the conditional under the umbrella of the epistemic conditional, i.e. uses that are unrelated to secondhand information, Abouda $(2001)$ and Celle $(2006,2007)$ take the opposite stance and argue that the primary meaning of the epistemic conditional is one of non-commitment. Kronning $(2002,2012)$ elaborates a theory that reconciles the modal and the evidential approaches by arguing that "zeromodalisation", i.e. non-commitment, and secondhand information ("médiation d'emprunt") are two facets of the epistemic conditional and cannot be disentangled. The epistemic conditional is defined by Kronning as both evidential ("médiatif") and modal.

Importantly, Dendale $(1993,2018)$ and Kronning $(2002,2012)$ highlight the potential of a grammatical marker to establish a link between epistemic modality and indirect access to information. Imagine you live on Avenue Kléber and actually see protesters setting your car alight during a violent demonstration. You cannot describe what is happening (a) or what has happened (b) using the conditional if you have witnessed that event:

(11) (a) \# Il y a des manifestants qui mettraient le feu à ma voiture.

'Apparently, protesters are setting my car alight.'

(b) \# Des manifestants auraient mis le feu à ma voiture.

'Apparently, protesters have set my car alight.'

Examples (11a) and (11b) are only felicitous if you have obtained that information indirectly from an assertive source, e.g. if your neighbour has called you and advised you to go and check what is happening to your car.

However, it seems excessive to claim that the epistemic conditional encodes secondhand information. I show below that reference to a previous report is not necessary, given the inferential potential of the epistemic conditional. The inferential meaning of the epistemic conditional should be considered in any attempt to clarify the connection between the epistemic conditional and reportative evidentiality. Most studies so far have focused on the inferential use of the epistemic conditional in questions and contrasted this use with the secondhand information use in declarative sentences (Tasmowski 2001, Bourova \& Dendale 2013, Squartini 2008). However, as pointed out by Provôt and Desclés (2012) and Rossari (2018), the epistemic conditional can also be inferential in declarative clauses and it can be difficult to tell reportative meaning and inferential meaning apart. This raises theoretical questions as to the evidential status of the epistemic conditional. The classification of evidence types proposed by Willett (1988) establishes conceptual boundaries within indirect evidence 
between reported evidence (hearsay) and inferred evidence, which does not seem to be borne out with the epistemic conditional.

The central claim made in this paper is that the epistemic conditional is a construction that expresses epistemic possibility. It affects the speaker's level of commitment and is highly compatible with evidential strategies that are not restricted to secondhand information, i.e. a specific type of information source. The epistemic conditional is not homogeneous with respect to information source. In journalistic discourse, its most frequent interpretation is reportative:

(12) Boris Johnson serait prêt à demander un report du Brexit à Bruxelles. (Le Monde, October 2019)

'Boris Johnson iscond reportedly ready to ask the EU for Brexit extension.'

The proposition is framed from a distant vantage point that is dubbed an epistemic frame in this paper. It is presented as an assumption and not as a fact. While reporting what someone said, the speaker disclaims responsibility for the proposition. This explains why the proposition can be felicitously denied:

(12) (a) Boris Johnson serait prêt à demander un report du Brexit à Bruxelles, mais je n’y crois pas.

'Boris Johnson iscond reportedly ready to ask the EU for Brexit extension, but I don't believe it.'

Denying an original reporting event would not be felicitous:

(12) (b) ??Boris Johnson serait prêt à demander un report du Brexit à Bruxelles, mais cela n'a pas encore été rapporté.

'Boris Johnson iscond reportedly ready to ask the EU for Brexit extension, but this has not been reported yet.'

However, even in journalistic discourse, the epistemic conditional does not necessarily encode oral report. In the following example, the evidential base for the utterance is the visual evidence provided by a famous picture that circulated on social media:

(13) C'est une photo de vacances un peu particulière. Le 23 mai, Nirmal Purja Magar (alias Nimsdai sur les réseaux sociaux), alpiniste anglo-népalais et ancien Gurkha des forces spéciales britanniques, postait sur les réseaux sociaux, à peine redescendu des sommets de l'Everest et du Lhotse, dans l'Himalaya, l'image d'une interminable file de grimpeurs emmitouflés avançant à la queue leu leu sur l'arête de neige et de roche qui conduit au Toit du monde : 8848 mètres, l'altitude à laquelle circulent les vols long-courriers. L'image fait aussitôt le tour de la planète, suscitant une avalanche de commentaires : l'Everest serait devenu une autoroute à touristes fortunés. Abolie la dernière frontière, fini le rêve, morte l'aventure!

Pas si sûr... L'ascension de la plus haute montagne du monde, à la frontière entre le Népal et la Chine, reste un sport dangereux. Douze personnes y ont trouvé la mort au printemps. Un record depuis l'hécatombe de 2015. [...] 
C'est le paradoxe de l'Everest: plus le matériel est performant, plus les données météo sont fines et plus son ascension se démocratise. Plus de monde, plus de morts. En chiffres absolus, pas relatifs. (Le Monde, October 2019)

'It's a special holiday picture. On May 23, Nirmal Purja Magar (aka Nimsdai on social networks), an English-Nepalese climber and former Gurkha as part of the British special forces, just back from Mount Everest and Lhotse in the Himalayas, posted on social networks the picture of an endless line of climbers wrapped in single file on the ridge of snow and rock that leads to the Roof of the World at 8,848 meters, the cruising altitude of long-haul flights. The picture immediately spread round the world, causing an avalanche of comments: Mount Everest hadcond become a highway for wealthy tourists. The last frontier had been abolished, the dream had ended, the adventure had died.

Not so sure ... Climbing the highest mountain in the world, on the border between Nepal and China, remains a dangerous sport. Twelve people died in the spring. A record since the slaughter of 2015. [...]

This is the paradox of Mount Everest: the more efficient the equipment - the more accurate the weather data - the more crowded the ascent. More people means a higher death toll in absolute number, not in relative number. $[\ldots]^{\prime}$

The statement in the conditional, as well as the three verbless sentences that follow, summarise the mainstream position that arose from the numerous comments triggered by a picture that depicts a conga line of climbers ascending Mount Everest. The role of the conditional is to set up an epistemic frame that specifies the point of view these statements anchor to.

The nature of information source is different in (12) and (13), as there is no original assertive source in (13). However, the tests used in (12a) and (12b) can be applied to (13). The proposition can be felicitously denied because as in (12), the point of view expressed is not the speaker's:

(13) (a) L'Everest serait devenu une autoroute pour touristes fortunés, mais je ne le crois pas.

'Apparently, Mount Everest hascond become a highway for rich tourists, but I don't believe it.'

The next paragraph, starting with "pas si sûr", provides an explanation for the speaker's reluctance to commit to the truth of the proposition in the statement modalised by the conditional. Not that the information the proposition is based on, i.e. the picture, is uncertain. But the view expressed in the proposition would be incomplete and too simplistic without taking relative figures into consideration.

The test used in (12b) can also apply to (13):

(13) (b) ??L'Everest serait devenu une autoroute pour touristes fortunés, mais cela n'a pas encore été rapporté.

'Mount Everest hascond apparently become a highway for rich tourists, but this has not been reported yet.' 
Hearsay does not necessarily require an original speech event. It may be based on visual evidence. However, this evidence is indirect and counts as a visual report. This explains why denying a report is not felicitous in (13b). This suggests that the nature of information source - whether it be based on visual or auditory experience - does not matter as long as a point of view different from the speaker's can be recovered. Therefore, I consider the conditional to serve a reportative function both in (12) and (13). In order to serve such a function, the conditional needs an epistemic frame. Importantly, the information that serves as an evidential base for the proposition is accessible and reflects a point of view that is not the speaker's. The epistemic frame can be made explicit in the following paraphrases:

(12) (c) Si les dernières informations sont vraies, Boris Johnson serait prêt à demander un report du Brexit à Bruxelles.

'If the latest reports are true, Boris Johnson iscond ready to ask the EU for Brexit extension.'

(13) (c) Si cette photo est réelle, l'Everest serait devenu une autoroute pour touristes fortunés.

'If this picture is real, Mount Everest hascond become a highway for rich tourists.'

What complicates the picture, however, is that the conditional may be used in cases that are not strictly reportative. It can be difficult to distinguish between the reportative and the inferential meaning of the epistemic conditional, as pointed out by Guentchéva (1994: 17), Rossari (2009) and Provôt and Desclés (2012):

(14) Le mouvement des collectivisations aurait concerné, au total, entre un million et demi et deux millions et demi de travailleurs, mais il est difficile d'en faire un bilan précis : il n'existe pas de statistiques globales et beaucoup d'archives ont été détruites. On peut toutefois s'appuyer sur les données fragmentaires publiées dans la presse, en particulier syndicale. Et sur les nombreux témoignages d'acteurs et d'observateurs du conflit. (Le Monde Diplomatique, December 2000)

'All in all, one and half to two and a half million people werecond involved in the wave of collectivisation, though precise figures are hard to come by. Although no general statistics are available and many archives were destroyed, much partial data published in the press, especially that of the unions, has survived. Above all, we have many accounts by people who took part in or observed the conflict.' (English Edition)

The context makes it clear that "one and half to two and a half million people were involved in the wave of collectivisation" is not a previous statement reported by the speaker. Rather than reporting, the speaker is attempting to estimate the extent of collectivisation based on different types of evidence such as archives, partial data, hearsay and various accounts. Some accounts may point to one million and a half people being involved while other accounts may well point to two million or two million and a half. This various evidence serves as a 
premise in an abductive inference that supports the speaker's estimate. ${ }^{11}$ An underlying protasis such as "if this evidence can be trusted" provides the epistemic frame that justifies the speaker's claim. The inferential nature of the conditional explains why it fails the diagnostics generally used to test reportative evidentiality. Under this reading, the proposition cannot be challenged:

(14) (a) ?? Le mouvement des collectivisations aurait concerné, au total, entre un million et demi et deux millions et demi de travailleurs, mais je n'en crois rien / $\mathrm{c}^{\prime}$ est faux..$^{12}$

'All in all, one and half to two and a half million people werecond involved in the wave of collectivisation, but I don't believe it / it's false.'

Denying the proposition sounds like a contradiction ${ }^{13}$ because the speaker cannot put forward an estimate and at the same time challenge it. This suggests that the speaker makes some commitment to the proposition, at least to its possibility (see Murray 2017: 17-18, Korotkova 2016: 39). The sources of information range from written data to witnesses' accounts, whose contents may vary. The speaker's evaluation involves cross-checking potentially discordant information. In any case, the speaker's estimate is not based on a specific type of evidence. To the extent that this estimate relies on the speaker's reasoning process, it is even possible to deny an original reporting event:

(14) (b) Le mouvement des collectivisations aurait concerné, au total, entre un million et demi et deux millions et demi de travailleurs, mais cela n'a pas encore été rapporté.

\footnotetext{
${ }^{11}$ For lack of space, the comparison of epistemic devoir with the epistemic conditional is beyond the scope of this paper. Nonetheless, it should be pointed out that the inferential capacity of the conditional is much more limited than that of epistemic devoir. As stressed by Dendale and De Mulder (1996), devoir allows inferring from cause to consequence and from consequence to cause. The epistemic conditional only allows inferring a plausible cause from available evidence in abductive reasoning as long as an epistemic frame can be recovered:

D'après la rumeur, Pierre serait rentré ['the rumour has it that Pierre has come back'] (if the rumour can be trusted);

Tiens, il y a de la lumière dans le salon de Pierre. Il serait rentré plus tôt que prévu ['Look, there is light in Pierre's living room. He must have come back earlier than planned'] (if I believe what I see).

However, it is not possible to draw a conclusive inference from a premise:

Il y a de la lumière dans le salon de Pierre. Il a d̂u rentrer. ${ }^{*}$ Il serait rentré ['There is light in

Pierre's room. He must have come back].

${ }^{12}$ If an assertive source is introduced by a framing prepositional phrase (" $\mathrm{d}$ 'après / selon cet historien" ['according to that historian']), the validity of the proposition is restricted to this source. As a result it can be challenged. See below.

${ }^{13}$ In this respect, the epistemic conditional is different from hearsay adverbs in English, whose reportative evidential function is well-established (Celle 2009) and stable. The proposition can be denied in the following example, which shows that the speaker does not commit to its truth: "Trump reportedly approved a \$2 million hospital bill from North Korea for Otto Warmbier, but that's not true." With respect to non-commitment, hearsay adverbs in English pattern exactly like reportative evidentials in general (see Korotkova 2016: 43) as they are not inferential.
} 
'One and half to two and a half million people werecond involved in the wave of collectivisation, but there have been no reports yet.'

In summary, only (12) and (13) unambiguously pass the diagnostics devised to test reportative evidentiality, while (14) does not. This suggests that the epistemic conditional is not homogeneous with respect to reportative evidentiality.

The conditional in (14) does not pattern like a typical reportative evidential. Firstly, the modalised claim cannot be felicitously denied, while it has been shown that reportatives are the only evidentials that can be denied by the same speaker (AnderBois 2014). This pattern, dubbed "reportative exceptionality" by AnderBois (2014), is considered to be crosslinguistically widely attested. ${ }^{14}$ According to AnderBois (2014), reportative exceptionality arises from a pragmatic perspective shift. This shift may not occur in (14a) because the modalised proposition reflects the speaker's perspective based on multiple accounts.

Secondly, a reporting event can be denied in (14b) because this utterance permits an inferential reading that relies more on the speaker's mode of knowing than on information source. By contrast, it is generally admitted that in languages that have a reportative evidential, a reporting event is presupposed and cannot be denied. Murray (2017: 21) argues that crosslinguistically, "sentences with evidentials make a commitment to the evidential proposition". Consequently, the evidential proposition cannot be denied. Noteworthy is the fact that an evidential adverb such as reportedly is not used in the translation of (14). In the English version published by Le Monde Diplomatique, the conditional was left out as it usually is. Arguably, the meaning of the conditional is not easily translatable in the absence of an assertive source. The assumption put forward by the speaker may be based on any kind of indirect evidence, but this evidence does not have to be secondhand information. This explains why a reporting event can be denied.

The diagnostics used so far were designed to test reportative evidential meaning in languages that have evidential affixes (see Murray 2017, AnderBois 2014). Applying those tests to the epistemic conditional produces mixed results. The epistemic conditional appears to pass the tests under a reportative reading, while it does not under an inferential reading. This result shows that the epistemic conditional is not homogeneous with respect to secondhand information. Under an inferential reading, the reportative function is not in the foreground.

What is required for the epistemic use of the conditional is an epistemic frame, not secondhand information. This predicts that the existence of a reporting event can be denied in inferential uses where the speaker's perspective is in the

\footnotetext{
${ }^{14}$ Faller (2002) even argues that in Quechua, the scope proposition is only presented in the case of reportative evidentials, whereas it is asserted in the case of all other evidentials.
} 
foreground. In that case, the conditional cannot be said to encode a specific type of information source. Such a view is in line with Wiemer's claim that in Romance languages the conditional is "the basis for evidential extensions" (2010: 78). In French as in other Romance languages, "these extensions are not restricted to hearsay but result in an undifferentiated indirect evidential function" (Wiemer 2010: 114).

This indirect evidential function holds for surprise contexts. Abductive reasoning may be triggered either by an unexpected report, as in (15), or by an unexpected state of affairs, as in (16) and (17):

(15) Katy Perry : son mari expulsé du Japon. Les services de l'immigration japonais ont procédé à l'expulsion du mari de la star, dimanche 22 mai dernier. Tiens, tiens ! Le gouvernement français ne serait donc pas le seul à pratiquer l'expulsion de ce qu'il considère comme des indésirables. Le Japon aussi s'y met. Russel Brand, l'époux de Katy Perry, a fait les frais de la politique nippone en matière d'immigration. Il a été expulsé. (Sketch Engine TenTen Corpus)

'Katy Perry: her husband was expelled from Japan. Japanese immigration services expelled the star's husband on Sunday May 22nd. Well well! So the French government iscond not the only one to expel those considered undesirable. Japon starts doing this too. Russel Brand, Katy Perry's husband, bore the consequences of Japan's immigration policy. He was expelled.'

(16) Certes, je me croirais fou, absolument fou, si je n'étais conscient, si je ne connaissais parfaitement mon état, si je ne le sondais en l'analysant avec une complète lucidité. Je ne serais donc, en somme, qu'un halluciné raisonnant. Un trouble inconnu se serait produit dans mon cerveau; un de ces troubles qu'essaient de noter et de préciser aujourd'hui les physiologistes ; et ce trouble aurait déterminé dans mon esprit, dans l'ordre et la logique de mes idées, une crevasse profonde. (Maupassant, Le Horla, cited in Celle 2008: 28)

'I certainly should think that I was mad, absolutely mad, if I were not conscious that I knew my state, if I could not fathom it and analyze it with the most complete lucidity. I should, in fact, becond a reasonable man labouring under a hallucination. Some unknown disturbance must havecond been excited in my brain, one of those disturbances which physiologists of the present day try to note and to fix precisely, and that disturbance must havecond caused a profound gulf in my mind and in the order and logic of my ideas.' (English Edition, GoogleBooks)

(17) Quoi! j'aimerais, se disait-elle, j'aurais de l'amour! Moi, femme mariée, je serais amoureuse! (Stendhal, Le rouge et le noir, cited in Celle 2007: 54)

'What! she said to herself. Can I lovecond him, feelcond love for him? Can I, a married woman, havecond fallen in love?' (Scarlet and Black, translated by Margaret Shaw)

In these examples, the source of information is the speaker. In (15), the conditional indicates that the speaker's expectation that the expulsion practice is limited to France is disconfirmed. The source of surprise is the report about Russel Brand's expulsion from Japan, which leads the speaker to update her belief. In (16) and (17), the speaker's surprise is triggered by some evidence the 
speaker has direct experience of. ${ }^{15}$ In both cases, unexpected evidence is directly perceptible. In these examples, the epistemic conditional takes on a mirative meaning (DeLancey 1997, Aikhenvald 2004). The reading is unambiguously nonreportative as these utterances offer the speaker's perspective on a proposition. Predictably, the diagnostics used to test reportative evidentiality fail:

$\left(15^{\prime}\right) \quad$ Tiens, tiens! Le gouvernement français ne serait donc pas le seul à pratiquer l'expulsion de ce qu'il considère comme des indésirables.

'Well well! So the French government iscond not the only one to expel those considered undesirable.'

(a) ??Mais ce n'est pas vrai.

'But that's not true.'

(b) Mais cela n'a pas encore été rapporté.

'But this has not been reported yet.'

In all three examples, evidence disconfirms the speaker's expectations, which is corroborated by additional elements such as an exclamation intonation in (17), exclamative "quoi" in (17) or "tiens" in (15), i.e. a grammaticalised imperative form of the verb tenir. Based on this evidence, the speaker may draw abductive inferences. Donc (as in examples 15 and 16) and alors frequently cooccur with the conditional. In (16), several assumptions are presented as plausible. Being unprepared for this unexpected turn of events, the speaker only commits to the possibility of the propositions, without committing to their truth.

This shows that the epistemic conditional is not motivated by the nature of information source. One may wonder what motivates its use in the various cases examined so far. Rossari (2009: 92-93) persuasively argues that the conditional encodes the speaker's lack of control over some situation. Such an approach suggests that how the speaker positions herself with respect to information and how she interacts with the addressee matters much more than information source. This is corroborated by my data.

In (12) and (13), the speaker does not have control over information because it is either unconfirmed or incomplete, i.e. unreliable. Note that information is not necessarily uncertain. It can simply be too partial for the speaker to commit to the truth of the proposition, as in (13). Whatever its source, this information reflects a point of view that is not the speaker's and the speaker assesses the proposition by disclaiming responsibility for it.

In (14), it is difficult to distinguish between reportative and inferential meaning. Nonetheless, the point of view that is expressed is the speaker's based on inferential evidence. The various information available is not sufficient for the

${ }^{15}$ In (16), the hypothetical conditional in the first sentence expresses irrealis meaning. This implies that in reality, the proposition "I don't think I am mad" is true. Madness being ruled out as an explanation for the subject's condition, alternative plausible explanations are put forward. These assumptions are expressed in the epistemic conditional. 
speaker to commit to the truth of the utterance. Partial information is the starting point of abductive reasoning. In that case, the speaker commits at least to the possibility of the proposition.

In (15), (16) and (17), the utterances in the conditional convey the speaker's perspective by marking that the information at hand is unexpected. This information may be either reported evidence (15) or self-related evidence (16 and 17). In the first case, the speaker makes an inference from surprising reported evidence. In the second case, the speaker has direct knowledge of the proposition. What is, then, the function of the conditional? It conveys that the speaker does not cognitively control unexpected new information. Clearly, the conditional has a mirative meaning. It marks information as new to the speaker in the sense of DeLancey:

[The mirative category] marks both statements based on inference and statements based on direct experience for which the speaker had no psychological preparation, and in some languages hearsay data as well. What these apparently disparate data sources have in common $[\ldots]$ is that the proposition is one which is new to the speaker, not yet integrated into his overall picture of the world. (DeLancey 1997: 35-36)

In the mirative meaning, the speaker believes that the proposition is true. However, the discrepancy between her belief and her expectations triggers epistemic distancing. From a distant vantage point, the speaker only commits to the possibility of the proposition.

The conditional specifically encodes that the speaker is resistant to cognitively assimilating an unexpected state of affairs. Although the speaker has direct experience of some disturbing evidence in (16) and (17), this does not translate into immediate awareness. ${ }^{16}$ The indicative would be acceptable and would mark the speaker's commitment to the truth of the propositions:

(16') Je ne suis donc, en somme, qu'un halluciné raisonnant. Un trouble inconnu s'est produit dans mon cerveau; un de ces troubles qu'essaient de noter et de préciser aujourd'hui les physiologistes; et ce trouble $a$ déterminé dans mon esprit, dans l'ordre et la logique de mes idées, une crevasse profonde.

'I am, in fact, a reasonable man labouring under a hallucination. Some unknown disturbance has been excited in my brain, one of those disturbances which physiologists of the present day try to note and to fix precisely, and that disturbance has caused a profound gulf in my mind and in the order and logic of my ideas.'

(17') Quoi ! j'aime, se disait-elle, j'ai de l'amour ! Moi, femme mariée, je suis amoureuse! 'What! she said to herself. I love him, I feel love for him. I, a married woman, have fallen in love.'

\footnotetext{
${ }^{16}$ Resorting to indirect evidential strategies in surprise contexts is a crosslinguistically robust phenomenon. See Aksu-Koç and Slobin (1986: 159), de Haan (2012: 1040), Peterson (2017: 61-64) among others.
} 
All in all, the epistemic conditional marks that information is being processed from a distant vantage point. This information being either unreliable or unexpected, the speaker does not have full control over it and does not treat it as knowledge, hence the indirect evidential strategy. Commitment to the factuality of the proposition is thus suspended, regardless of the speaker's belief as to the truth of the proposition.

\section{REPORTED SPEECH AND FRAMING PREPOSITIONAL PHRASES}

The epistemic conditional is not felicitous after a factive predicate such as savoir (know): ${ }^{17}$

(18) ?? Les enquêteurs savent que l'incendie se serait déclaré à 18 heures.

'The investigators know that the blaze brokecond out at 6 pm.'

If knowledge has been acquired, only the indicative may be used in the embedded clause. However, the epistemic conditional may be embedded under verbs of saying. A verb of saying asserts that a report took place. The conditional in the embedded clause marks the proposition as possibly true. Whether epistemic modality is anchored to the speaker or to the reporter may be difficult to determine. The conditional typically indicates that the speaker is distancing herself from the report:

(19) Le professeur Mathieu Raux, qui travaille au service de réanimation de la PitiéSalpêtrière, a expliqué à BFM-TV que des dégradations auraient eu lieu par la suite après la tentative d'intrusion : «Dans d'autres services de l'hôpital, il y a eu des exactions. Dans le même bâtiment, il y a eu deux heures plus tard la perte de l'ensemble du matériel informatique vandalisé dans le service de chirurgie digestive.» (Le Monde, May 2019)

'Professor Mathieu Raux, who works in the intensive care unit at La Pitié-Salpêtrière Hospital told BFM-TV that damage tookcond place following the intrusion attempt: "In some other units in the hospital, there were acts of violence. In the same building, all the hardware was trashed and lost two hours later in the digestive surgery department."'

The clause in the conditional (auraient eu lieu) embedded under the verb of saying (a expliqué) corresponds to the speaker's reformulation of the sequence of direct speech enclosed in quotation marks. This difference in perspective explains why the reported speech sequence and the quotation are not redundant, although they refer to the same events. As the direct speech content is reported in the

\footnotetext{
${ }^{17}$ Searching the Timestamped JSI webcorpus with Skech Engine yielded 52 hits of "savoir que" followed by the conditional. Out of those 52 occurrences, 51 were either hypothetical or temporal conditionals. Only 1 was an instance of the epistemic conditional, but in that case savoir was not a factive verb as it was preceded by verb faire. Faire savoir is a verb of communication meaning to inform.
} 
indicative, the reporter (Le professeur Mathieu Raux) clearly commits to the truth of the propositions (there having been acts of violence, there having been the loss of computer hardware). Contextually, the qualification conveyed by the conditional can only be anchored to the speaker, not to the reporter. This does not mean, however, that the conditional has a reportative function. First, report is explicitly marked by the verb of saying and there is no need to mark it again in the embedded clause. Second, the conditional suggests that the report gives rise to the speaker's reformulation of the whole reported speech chunk. The actual speech event enclosed in quotation marks is processed as an assumption, which impacts the speaker's level of commitment to the proposition. The conditional indicates that the speaker does not take responsibility for this proposition. While the reporter commits to the truth of the propositions in the quotation, the speaker only commits to the possibility of the proposition in the embedded proposition. In this way, the conditional conveys the speaker's perspective on the proposition.

However, the conditional in reported speech may be anaphoric to the conditional within the corresponding quotation. This raises the question of the origo of the conditional in reported speech and more generally in reportative contexts:

(20) Des Français feraient partie du groupe d'Occidentaux enlevés en Ethiopie [headline] Des Français se trouveraient parmi les Occidentaux portés disparus dans le nord de l'Ethiopie, a déclaré, vendredi 2 mars, le ministre des affaires étrangères français, Philippe Douste-Blazy. «D'après les informations dont nous disposons, des Occidentaux auraient été enlevés dans le nord de l'Ethiopie», a indiqué le ministre. (Le Monde, cited in Celle 2008: 26)

‘Western tourists reportedly includingcond French nationals kidnapped in Ethiopia [headline]

Western tourists, includingCond French nationals, are reported missing, the French foreign minister said today. 'We understand that a number of Western tourists werecond kidnapped in northern Ethiopia,' P. Douste-Blazy said.' (English Edition)

In (20), the conditional appears in the headline (feraient partie), in a quotation (auraient été enlevés) and in reported speech (se trouveraient). In the quotation, the conditional (auraient été enlevés) indicates that the reporter (the Minister) infers the possibility of the proposition based on available evidence. Given that the claim made in the quotation is qualified by the reporter (auraient été enlevés), the interpretation of the conditional in the reported speech sequence (se trouveraient) is ambiguous. As in (19), the conditional (se trouveraient) may be anchored to the speaker and convey the speaker's reformulation of the original speech event. In addition, it may be anaphoric to the conditional in the quotation (auraient été enlevés) and specify the reporter's perspective on the proposition. In that case, epistemic modality is reported and signals that the reporter disclaims responsibility for the proposition. In any case, it is difficult to tease apart the 
speaker's and the reporter's perspectives in reported speech. This pattern can be analysed as an instance of mixed enunciation (Celle 2008: 26-27).

Let us now move on to framing prepositional phrases in conditional utterances, which, unlike (19) and (20), do not contain a verb of saying. First, it should be stressed once again that in French, there is no need to use the conditional, even in the absence of a verb of saying:

(21) Selon l'OCDE, l'essor des échanges commerciaux a créé plus d'emplois qu'il n'en a détruits. (Le Monde, April 2019)

'According to $\mathrm{OECD}$, the expansion of trade-related activity has created more jobs than it has destroyed.'

(22) Selon le parquet, l'un des suspects est un mineur déjà condamné par le tribunal pour enfants pour association de malfaiteurs terroriste. Il avait été interpellé en février 2017, à l'âge de 15 ans, alors qu'il cherchait à se rendre en Syrie, avant d'être condamné à une peine de trois ans de prison dont deux assortis d'un sursis avec mise à l'épreuve. (Le Monde, April 2019)

'According to prosecutors, one of the suspects is a minor who has already been convicted of conspiracy in connection with a terrorist enterprise. He had been arrested in February 2017 at the age of 15 as he was trying to get to Syria, before being sentenced to a suspended term of three years' imprisonment with two years' probation.'

In (21) and (22), the selon prepositional phrase provides a frame that restricts the validity of the propositions within its scope. This can be shown by denying the proposition: ${ }^{18}$

(21') Selon l'OCDE, l'essor des échanges commerciaux a créé plus d'emplois qu'il n'en a détruits. Mais c'est faux en réalité. Mais je n'en crois rien.

'According to $\mathrm{OCDE}$, the expansion of trade-related activity has created more jobs than it has destroyed. Actually, it's false. But I don't believe it.'

It is worth noting that in (22), selon scopes not only over the proposition it precedes, but also over the next one in the following sentence. The tenses used in these propositions are the indicative past perfect (avait été interpellé) and the indicative present (est). The prepositional phrase provides the perspective relative to which the propositions are true and there is no need to specify secondhand information at the verb level in the propositions under the scope of selon. What is then the function of the conditional in utterances framed by selon? As in the case of indirect speech (19 and 20), it indicates that the speaker disclaims responsibility for the proposition. However, the conditional may be ambiguous (as in 20) as to which origo it anchors to:

\footnotetext{
${ }^{18}$ This does not mean that the speaker rejects the validity of the proposition, but rather that the speaker's attitude to the proposition is not specified, which makes denial possible. The framing prepositional phrase only conveys OECD's point of view.
} 
(23) Selon les informations du Parisien, ces violences présumées auraient été très légères : à la récréation, Jean Willot aurait demandé à l'élève de ne pas rester assis sur une marche d'escalier. Ce dernier aurait refusé et le professeur aurait alors dû le prendre par le bras pour lui faire descendre les marches. Une version que conteste la famille Willot, qui parle d'une simple punition verbale sans rapport physique. (Le Monde, April 2019)

'According to Le Parisien, the alleged violent acts werecond not serious: during the break, Jean Willot askedcond the pupil not to stay seated on a stair step. The pupil refusedcond and the teacher hadcond to take him by the arm to make him go down the stairs. This version of the facts is contested by Willot's family. They maintain he only punished the pupil verbally, not physically.'

In (23), the selon-phrase provides an epistemic frame that restricts the validity of the subsequent propositions. Several propositions are under the scope of selon. In this respect, the conditional does not pattern differently from the past perfect in (22). The main difference between (22) and (23) is that in (23), the conditional undermines the factual status of these propositions. In addition, it blurs their modal anchoring by making it difficult to distinguish between a reportative reading and an inferential reading. The conditional may be anchored to the assertive source (les informations $d u$ Parisien). This reading is likely to apply to the conditional forms that appear after the colon (aurait demandé, aurait refusé, aurait alors $d \hat{u}$ ), where the events listed were presumably originally reported by Le Parisien. A second reading is possible: while reporting the Parisien's version of facts, the speaker is simultaneously inferring what may have happened on the basis of the evidence found in Le Parisien. This reading applies to the first conditional form (auraient été), as the first proposition (ces violences auraient été très légères) summarizes the subsequent ones and offers the speaker's perspective on the events reported in Le Parisien.

Selon-phrases in conditional utterances may be taken as the starting point of a reformulation, in which case the inferential component of the conditional is highlighted:

(24) Selon les premiers éléments de l'enquête, c'est dans les combles de Notre-Dame de Paris que l'incendie aurait démarré, peu avant 19 heures. (Le Monde April 2019)

'According to the first results of the investigation, it is in the roof of Notre Dame Cathedral in Paris that the fire brokecond out, shortly before 7 pm.'

The results of an investigation cannot be construed as the same report emanating from different sources. Rather, an assumption is drawn from multiple reports and various types of evidence. Rossari (2018: 233) labels such uses "Hypothetical Interpretation in the Strict Sense" (IHS). It seems that this interpretation is not limited to framing prepositional phrases, as it can be extended to unframed occurrences of the conditional, such as (14), repeated here for convenience: 
(25) Le mouvement des collectivisations aurait concerné, au total, entre un million et demi et deux millions et demi de travailleurs, mais il est difficile d'en faire un bilan précis: il n'existe pas de statistiques globales et beaucoup d'archives ont été détruites. On peut toutefois s'appuyer sur les données fragmentaires publiées dans la presse, en particulier syndicale. Et sur les nombreux témoignages d'acteurs et d'observateurs du conflit. (Le Monde Diplomatique, December 2000)

'All in all, one and half to two and a half million people werecond involved in the wave of collectivisation, though precise figures are hard to come by. Although no general statistics are available and many archives were destroyed, much partial data published in the press, especially that of the unions, has survived. Above all, we have many accounts by people who took part in or observed the conflict.' (English Edition)

Undoubtedly, a reportative reading is the only one possible when a specific assertive source is identified:

(26) Durant le Haut Moyen Age, jusqu'à la fin des Croisades, les léproseries avaient multiplié sur toute la surface de l'Europe leurs cités maudites. Selon Mathieu Paris, il y en aurait eu jusqu'à 19000 à travers toute la chrétienté. En tout cas, vers 1266, dans le temps où Louis VIII établit pour la France le règlement des léproseries, on en recense plus de 2 000. (Michel Foucault, Histoire de la folie à l'âge classique, 1972)

'From the High Middle Ages to the end of the Crusades, leprosariums had multiplied their cities of the damned over the entire face of Europe. According to Mathieu Paris, there werecond as many as 19,000 of them throughout Christendom. In any case, around 1226, when Louis VIII established the lazar-house law for France, more than 2,000 appeared on the official registers.' (translated by Richard Howard)

However, even in such a straightforward reportative case, the speaker's assessment of the proposition is superimposed by the conditional. The conditional encodes that the speaker disclaims responsibility for the proposition. Even if Mathieu Paris's point of view is presented as an argument that adds force to the speaker's claim that leprosariums had multiplied, as it points to a high-end estimate ("as many as 19,000"), the speaker remains only committed to the truth of the proposition that follows ("around 1226 [...] more than 2000 appeared on the official registers"). Note that in English, there is no equivalent to the modalisation conveyed by the conditional, as the proposition framed by according to can only express Mathieu Paris's point of view and not the speaker's assessment.

In reportative contexts where report is encoded either by a verb of saying or by a framing prepositional phrase, the conditional is used to disclaim responsibility. Any contextually available evidence serves as a basis for inferential reasoning, thereby superimposing the speaker's perspective onto the initial perspective holder's, i.e. the reporter's. 


\section{THE EPISTEMIC CONDITIONAL IN CONJECTURAL POLAR QUESTIONS}

The epistemic conditional may be found in interrogative sentences. In accounts that incorporate secondhand information in the meaning of the epistemic conditional, this use is often considered to be peculiar (Bourova \& Dendale 2013: 183). Tasmowski (2001) suggests that the reportative conditional in assertions and the epistemic conditional in questions are in complementary distribution, as two facets of the evidential conditional realized in different speech acts. In our approach, the conditional is not deemed to be marker of secondhand information. Such a position allows treating the epistemic conditional in statements and in questions in a unified fashion (see Rossari 2018).

In interrogative sentences, the inferential meaning of the conditional is activated:

(27) Ai-je bien entendu? balbutia-t-elle indignée, que signifient ces mots de dette et de paiement? Seriez-vous venu me proposer un marché? (Frantext)

'Did I get it right? she stammered, outraged. What do the words «debt» and «payment» mean? Havecond you come to propose a deal to me?'

(28) Real Madrid: Zidane ne serait-il pas assez payé? La presse espagnole a révélé jeudi que Zinédine Zidane n'était payé que 300.000 euros nets en tant qu'entraîneur adjoint du Real Madrid. Un salaire bien en-deça de ses autres collègues des clubs espagnols. (Sketchengine Timestamped JSI web corpus)

‘Real Madrid: Iscond Zidane poorly paid? The Spanish press reported on Thursday that Zinédine Zidane only got 300,000€ net salary as assistant coach at Real Madrid. A salary way below his fellow coaches' in other Spanish clubs.'

The inferential reasoning takes an unexpected state of affairs as a starting point. In (27), in an attempt to explain why the words "debt" and "payment" were used by the addressee, the speaker puts forward a putative cause presented as a plausible assumption. The proposition "you come to propose a deal to $\mathrm{me}^{\text {" }}$ is drawn from the evidence provided by the words heard by the speaker. In (28), an assumption is suggested on the basis of an unexpected news release.

According to Diller (1977: 2-3), the conditional in polar questions introduces a presupposition that changes the illocutionary nature of the speech act. The evidence the speaker relies on weakens the interrogative force and provides the question with an assertive force. Diller (1977: 6-7) further argues that it is not possible to coerce a choice between yes and no, which shows that the question is biased. For instance, the following continuation is not acceptable with the conditional:

$\left(27^{\prime}\right)$ *Seriez-vous venu me proposer un marché, oui ou non?

'Havecond you come to propose a deal to me, yes or no?'

whereas it is perfectly acceptable with the present, a tense that does not alter the illocutionary nature of an information-seeking question: 
(27") Êtes-vous venu me proposer un marché, oui ou non?

'Have you come to propose a deal to me, yes or no?'

The conditional in polar interrogative sentences is triggered by an unexpected state of affairs. It does not follow that the conditional is to be treated on a par with evidentials. As stated above, in such questions, the conditional is speaker-oriented, exactly as in inferential declarative sentences. Given the deictic nature of the epistemic conditional that I have argued for, this comes as no surprise. However, this behavior shows that the epistemic conditional is not primarily evidential. Contrast the conditional in French and the hearsay adverb in English in the following pair:

(29) Zidane serait-il mal payé?

'Iscond Zidane poorly paid?'

(30) Is Zidane reportedly poorly paid?

In (29), the speaker's inferential reasoning is based on available evidence. This can be paraphrased with "I have evidence that $p$ ". The question is not about the evidence that the addressee has: "Do you have evidence that $\mathrm{p}$ " is not a felicitous paraphrase for (29).

By contrast, reportedly in (30) illustrates a typical pattern of evidentials in polar questions. The question does not presuppose that the speaker has evidence that $\mathrm{p}$. The paraphrase " $I$ have evidence that $\mathrm{p}$ " is not felicitous because the question is about the evidence the addressee has. In an evidential pattern, the question is taken to mean "Do you have evidence that p?".

In languages that have an evidential system, evidential marking is reported to be less frequent in interrogatives than in declaratives (Aikhenvald 2004: 242; San Roque, Floyd \& Norcliffe 2017: 129). Crosslinguistically, speaker's perspective in questions is rare (Aikhenvald 2004: 244, Sun 2018: 59-60) and mostly found in content questions (San Roque, Floyd \& Norcliffe 2017). Evidentials in interrogatives generally indicate "the expected source of evidence for the requested answer" (Murray 2017: 44). They undergo an interrogative flip from the speaker to the addressee (Murray 2017: 44, Korotkova 2016: 11), as does the hearsay adverb in (30). The conditional, however, is anchored to the speaker who remains the evidence holder in conjectural questions. This suggests that the conditional does not pattern like a typical evidential. ${ }^{19}$ An unexpected state of affairs provides direct evidence that triggers an inferential process. However, perspective-shifting is not possible with the conditional, which sets it apart from reportative evidentials.

\footnotetext{
${ }^{19}$ An exception to perspective-shifting in evidential questions is reported by San Roque, Floyd \& Norcliffe (2017: 131). In Duna, the reasoning evidential marker nei may not shift to the addressee in mirative contexts.
} 
To sum up, this type of conjectural question is syntactically a question. Semantically, conjectural interrogative sentences denote a set of two propositions (Yes, Zidane is poorly paid and its complement No, Zidane is not poorly paid). Pragmatically however, as pointed out by Diller (1977), conjectural questions are assertive rather than interrogative. They signal that a conjecture is inferred from controversial or unexpected information in order to account for a surprising state of affairs. The evidential presupposition the speaker relies on indicates that she knows the answer. Although such questions may be answered in interactional contexts, they do not require an answer. From a discursive point of view, they offer a powerful argumentative means to put forward a speaker-oriented assumption without having to make a commitment to that claim.

\section{CONCLUSION}

It is notoriously difficult to disentangle epistemic modality and evidentiality. The epistemic conditional is a case in point, all the more so as French has a tensemodal system and does not require marking information source. In this paper, I have proposed that evidentiality is conceptualized as an extension of epistemic modality. I have argued that the inferential, reportative and mirative uses of the epistemic conditional are part of an indirect evidential strategy. Building on Langacker (2017) and Rossari $(2009,2018)$, I have proposed that such a strategy is implemented when the speaker lacks control over information. The non-factual status of the proposition is then encoded by the epistemic conditional. A conceptual separation between reportative evidence and other types of evidence seems unwarranted, as the conditional may have an inferential function even in reportative contexts.

Strikingly, the speaker's perspective is prevalent both in declarative and interrogative sentences, which lends support to the deictic dimension of the epistemic conditional, rather than to a core secondhand evidential component. This suggests that the encoding of information source, which is the hallmark of evidentiality in languages that have an evidential system, does not map the evidential extensions of the conditional in a language that has a tense-modal system. In French, the evidential extensions of the epistemic conditional encode the speaker's lack of control over information, not information source.

The epistemic frame entailed by the epistemic conditional affects the speaker's level of commitment. In reportative contexts, the speaker disclaims responsibility for the modalised proposition. In inferential and mirative contexts, even if the speaker believes the proposition to be true, the proposition is presented as an assumption until full knowledge has been acquired; the speaker only commits to the possibility of the proposition. The evidential scenario reflects how the speaker cognitively processes information in the acquisition of knowledge. It may encompass report, inference and surprise. Opting for this scenario creates a highly argumentative strategy. 
One of the benefits of this analysis is that it allows treating the epistemic conditional in declarative sentences and in so-called "conjectural questions" in a unified way. The puzzle of the epistemic conditional can be resolved if these two epistemic uses are conceptually related. We would also suggest that this analysis ties in with the observation that the conjectural meaning appeared earlier than the reportative meaning.

\section{BIBLIOGRAPHY}

ABOUDA, L. (2001), «Les emplois journalistique, polémique et atténuatif du conditionnel. Un traitement unitaire», in Le conditionnel en français, Dendale, P. \& Tasmowski, L. (eds.), Metz, Université de Metz, 277-294.

AikHEnVAlD, A. Y. (2004), Evidentiality, Oxford-New York, Oxford University Press.

AKSU-KOÇ, A. \& SLOBIN, D. I. (1986), «A Psychological Account of the Development and Use of Evidentials in Turkish», in Evidentiality: The Linguistic Coding of Epistemology, Wallace, L. Ch. \& Nichols, J. (eds.), Norwood, Ablex, 159-167.

ANDERBOIS, S. (2014), «On the Exceptional Status of Reportative Evidentials», Semantics and Linguistic Theory, 24, 234-54. Retrieved from: <https://doi.org/10.376 5/salt.v24i0.2424>.

AZZOPARDI, S. \& BRES, J. (2014), «Futur, conditionnel, et effets de sens de conjecture et de rejet en interrogation partielle», in SHS Web of Conferences 8, Neveu, F., Blumenthal, P., Hriba, L., Gerstenberg, A., Meinschaefer, J. \& Prévost, S. (eds.), EDP Sciences, 3003-3013. Retrieved from: <https://doi.org/10.1051/shsconf/20140801014>.

Bourova, V. \& Dendale, P. (2013), «'Serait-Ce Un Conditionnel de Conjecture?'; Datation, Évolution et Mise En Relation Des Deux Conditionnels à Valeur Évidentielle», Cahiers Chronos, 26, 183-200.

Bourova, V. \& TASMOWSKI, L. (2007), «La Préhistoire Des Futurs Romans - Ordre Des Constituants et Sémantique», Cahiers Chronos, 19, 25-41.

BRES, J., AZZOPARDI, S. \& SARRAZIN, S. (2012), «Le Conditionnel En Français: Énonciation, Ultériorité Dans Le Passé et Valeurs Modales», Faits de Langues, 40, 37-43.

BYBEe, J. L., PERKINS, R. D. \& PAgLIUCA, W. (1994), The Evolution of Grammar: Tense, Aspect, and Modality in the Languages of the World, Chicago, University of Chicago Press.

CAUDAL, P. (2018), «Vers une approche constructionnelle des structures au conditionnel», Langue francaise, 200(4), 49-61.

CELLE, A. (2006), Temps et Modalité: L'anglais, Le Francais et l'allemand En Contraste, 7, BernNew York, P. Lang.

Celle, A. (2007), «Analyse Unifiée Du Conditionnel de Non Prise En Charge En Français et Comparaison Avec l'anglais», Cahiers Chronos, Etudes sémantiques et pragmatiques sur le temps, l'aspect et la modalité, 19, 43-61.

CElle, A. (2008), «Tense, Modality and Commitment in Modes of Mixed Enunciation», Belgian Journal of Linguistics, 22 (December), 15-36. Retrieved from: $<$ https://doi.org/10.1075/bj1.22.02cel>.

CELle, A. (2009), «Hearsay Adverbs and Modality», in Modality in English 58, Salkie, R., Busuttil, P. \& van der Auwera, J. (eds.), Berlin-New York, Mouton de Gruyter, 269294. Retrieved from: <https://doi.org/10.1515/9783110213331.269>. 
CRUSCHINA, S. \& REMBERGER, E.-M. (2008), «Hearsay and Reported Speech: Evidentiality in Romance», Rivista di Grammatica Generativa, 33, 95-116.

DeLANCEY, S. (1997), «Mirativity: The Grammatical Marking of Unexpected Information», Linguistic Typology, 1(1), 33-52.

DENDALE, P. (1993), «Le Conditionnel de l'information Incertaine: Marqueur Modal Ou Marqueur Évidentiel?», in Actes du XXe Congrès International de Linguistique et Philologie Romanes: Université de Zurich (6-11 avril 1992), vol. 1, Hilty, G. (ed.), Tübingen, Fancke, 164-176.

DENDALE, P. (2018), «Évidentialité ou non-prise en charge? Le cas du conditionnel épistémique en français. Une réanalyse», Langue francaise, 200(4), 63-76.

Dendale, P. \& De Mulder, W. (1996), «Déduction Ou Abduction: Le Cas de 'devoir' Inférentiel», in L'énonciation Médiatisée, Guentchéva, Z. (ed.), Louvain, Peeters, 305318.

DILleR, A.-M. (1977), «Le Conditionnel, Marqueur de Dérivation Illocutoire», Semantikos, 2, 1-17.

FALLER, M. T. (2007), «Evidentiality below and above Speech Acts», unpublished manuscript.

FALLeR, M. T. (2002), «Semantics and Pragmatics of Evidentials in Cuzco Quechua», PhD dissertation, Stanford, Standford University.

GosseliN, L. (2001), «Relations Temporelles et Modales Dans Le "conditionnel Journalistique"», in Le Conditionnel en Français, Dendale, P. \& Tasmowski, L. (eds.), Metz, Université de Metz, 45-66.

GRUNIG, B.-N. (1993), «Pour Une Conception Dynamique Du Sujet», in Subjecthood and Subjectivity. The Status of the Subject in Linguistic Theory, Yaguello, M. (ed.), Paris, Ophrys, 125-137.

GuentchÉvA, Z. (1994), «Manifestations de La Catégorie Du Médiatif Dans Les Temps Du Français», Langue Francaise, 102, 24-40.

GuENTCHÉvA, Z. (ed.) (1996), L'énonciation médiatisée 1, Bibliothèque de l'information grammaticale 35, Louvain-Paris, Peeters.

HAAN, F. DE (2012), «Evidentiality and Mirativity», in The Oxford Handbook of Tense and Aspect, Binnick, R. (ed.), Oxford, Oxford University Press, 1020-1046. Retrieved from: <https://doi.org/10.1093/oxfordhb/9780195381979.013.0036>.

HAILlET, P. (2001), «A Propos de l'interrogation Totale Directe Au Conditionnel», in Le Conditionnel en Français, Dendale P. \& Tasmowski L. (eds.), Metz, Université de Metz, 295-330.

KOROTKOVA, N. (2016), «Heterogeneity and Uniformity in the Evidential Domain», PhD Dissertation, Los Angeles, University of California. Retrieved from: $<$ http://semanticsarchive.net/Archive/TlmNzI5N/nkorotkova2016-dissheterogene ityuniformity.pdf $>$.

KorZEN, H. \& HENNING, N. (2001), «Le Conditionnel: Niveaux de Modalisation», in Le Conditionnel en Français, Dendale, P. \& Tasmowski, L. (eds.), Metz, Université de Metz, 125-146.

KRONNING, H. (2002), «Le conditionnel «journalistique »: médiation et modalisation épistémiques», Romansk Forum, 16 (2002/2), 561-575.

KRONNING, H. (2012), «Le conditionnel épistémique: propriétés et fonctions discursives», Langue francaise, 173(1), 83-97. 
LANGACKER, R. W. (2017), «Evidentiality in Cognitive Grammar», in Pragmatics $\mathcal{E}$ Beyond New Series, Marín Arrese, J. I., Haßler, G. \& Carretero, M. (eds.), Amsterdam, John Benjamins Publishing Company, 271:13-55. Retrieved from: <https://doi.org/ 10.1075/pbns.271.02lan>.

Moeschler, J. \& Reboul, J. (2001), «Conditionnel et Assertion Conditionnelle», in Le Conditionnel en Français, Dendale, P. \& Tasmowski, L. (eds.), Metz, Université de Metz, 147-167.

MurRAY, S. E. (2017), The Semantics of Evidentials, Oxford-New York, Oxford University Press.

PATARD, A. (2017), «Du conditionnel comme constructions ou la polysémie du conditionnel», Langue francaise, 194(2), 105-124.

PETERSON, T. (2017), «Grammatical Evidentiality and the Unprepared Mind», in Expressing and Describing Surprise, Celle, A. \& Lansari, L. (eds.), Amsterdam, John Benjamins Publishing Company, 92:51-89. Retrieved from: $<$ https://doi.org/10.1075/bct.92.03pet $>$.

PROVÔT, A. \& DESCLÉS, J.-P. (2012), «Existe-t-Il Un ‘Conditionnel Médiatif’ En Français?», Faits de langue, 40, 45-52. Retrieved from: <https://doi.org/info:doi/10.37 26/431382_45>.

ROSSARI, C. (2009), «Le conditionnel dit épistémique signale-t-il un emprunt?», Travaux neuchâtelois de linguistique, 51, 75-96.

ROSSARI, C. (2018), "“Serait-ce elle la coupable, o sarà invece lui?" L'insinuation au moyen des questions en français et en italien: quelles formes pour quels effets?», in L'interrogative en français, Béguelin, M.-J., Coveney, A., Guryev, A. (eds.), Bern, Peter Lang, 229-246.

SAN RoQue, L., Floyd, S. \& NorClifFe, E. (2017), «Evidentiality and Interrogativity», Lingua, Essays on evidentiality, 186-187 (January), 120-143. Retrieved from: $<$ https://doi.org/10.1016/j.lingua.2014.11.003>.

SQUARTINI, M. (2008), «Lexical vs. Grammatical Evidentiality in French and Italian» Linguistics, 46(5). Retrieved from: <https://doi.org/10.1515/LING.2008.030>.

SUN, J. T.-S. (2018), «Evidentials and Person», in The Oxford Handbook of Evidentiality, Aikhenvald, A. (ed.), Oxford-New York, Oxford University Press, 47-63. Retrieved from: <https://doi.org/10.1093/oxfordhb/9780198759515.013.2>.

TASMOWSKI, L. (2001), «Questions Au Conditionnel», in Le Conditionnel en Français, Dendale, P. \& Tasmowski, L. (eds.), Metz, Université de Metz, 331-344.

WIEMER, B. (2010), «Hearsay in European Languages: Toward an Integrative Account of Grammatical and Lexical Marking», in Linguistic Realization of Evidentiality in European Languages, Berlin-Boston, De Gruyter Mouton, 59-130. Retrieved from: $<$ https://doi.org/10.1515/9783110223972.59>.

WiLlett, T. (1988), «A Cross-Linguistic Survey of the Grammaticization of Evidentiality», Studies in Language 12(1), 51-97. Retrieved from: $<$ https://doi.org/10.1075/sl.12.1.04wil>. 